\title{
Inhibitory effect of aqueous dandelion extract on HIV-1 replication and reverse transcriptase activity
}

\author{
Huamin Han ${ }^{1,2}$, Wen He $e^{1,2,5}$, Wei Wang ${ }^{1,3}$ and Bin Gao ${ }^{1,4^{*}}$
}

\begin{abstract}
Background: Acquired immunodeficiency syndrome (AIDS), which is caused by the human immunodeficiency virus (HIV), is an immunosuppressive disease that results in life-threatening opportunistic infections. The general problems in current therapy include the constant emergence of drug-resistant HIV strains, adverse side effects and the unavailability of treatments in developing countries. Natural products from herbs with the abilities to inhibit HIV-1 life cycle at different stages, have served as excellent sources of new anti-HIV-1 drugs. In this study, we aimed to investigate the anti-HIV-1 activity of aqueous dandelion extract.

Methods: The pseudotyped HIV-1 virus has been utilized to explore the anti-HIV-1 activity of dandelion, the level of HIV-1 replication was assessed by the percentage of GFP-positive cells. The inhibitory effect of the dandelion extract on reverse transcriptase activity was assessed by the reverse transcriptase assay kit.

Results: Compared to control values obtained from cells infected without treatment, the level of HIV-1 replication and reverse transcriptase activity were decreased in a dose-dependent manner. The data suggest that dandelion extract has a potent inhibitory activity against HIV-1 replication and reverse transcriptase activity. The identification of HIV-1 antiviral compounds from Taraxacum officinale should be pursued.

Conclusions: The dandelion extract showed strong activity against HIV-1 RT and inhibited both the HIV-1 vector and the hybrid-MoMuLV/MoMuSV retrovirus replication. These findings provide additional support for the potential therapeutic efficacy of Taraxacum officinale. Extracts from this plant may be regarded as another starting point for the development of an antiretroviral therapy with fewer side effects.
\end{abstract}

\section{Background}

Human immunodeficiency virus type 1 (HIV-1) is the causative agent of acquired immunodeficiency syndrome (AIDS). This disease represents a huge concern for global public health. Currently, there is no effective vaccine for HIV-1 [1]; thus, prevention and antiviral drugs are the only option to decrease morbidity and mortality in HIV-1-infected individuals. Several classes of antiretroviral drugs have been developed targeting viral proteins at different stages of the HIV-1 life cycle or host factors. Highly active antiretroviral therapy (HAART) [2], which typically utilizes a protease inhibitor in combination with a nucleoside and/or nonnucleoside reverse transcriptase inhibitor, is commonly used to treat HIV-1 infected patients. The general problems in current HIV

\footnotetext{
* Correspondence: bgao2004@gmail.com

'CAS Key Laboratory of Pathogenic Microbiology and Immunology (CASPMI), Institute of Microbiology, Chinese Academy of Sciences, Beijing, PR China Full list of author information is available at the end of the article
}

therapy are the constant emergence of drug-resistant HIV strains, adverse side effects and the unavailability of treatments in developing countries. Thus, developing cost-effective, highly-specific and antiresistant drugs are in urgent need.

Natural products, especially those derived from plants, have long been recognized as excellent sources of new anti-HIV-1 drugs. Some of them exhibit inhibitory activity against several HIV-1 processes, including viral entry, reverse transcription, replication, integration, virus maturation, and virion budding. Some of these compounds have been clinically tested, with favorable results [3-8]. Limonoid and nomilin, which are isolated from the seed of Citrus bergamia, inhibit both HTLV-1 and HIV-1 reverse transcriptase (RT) activities [9]. Betulinic acid, a triterpenoid isolated from the methyl alcohol extract of the leaves of Syzigium claviflorum, and novel betulinic acid derivatives have been used as potent antiHIV agents $[10,11]$, and new mechanisms for these

\section{C)


compounds have been identified [12-14]. These compounds have become a new class of anti-HIV drugs. Phase I and II studies have reported that single oral dose of bevirimat, derived from a betulinic acid-like compound, was well tolerated and demonstrated a dosedependent reduction in viral load. Derivative IC9564 also competed with gp120/CD4 complexes for binding to chemokine receptors, thus acting as an entry inhibitor that can potently inhibit a broad spectrum of primary HIV-1 isolates by targeting the V3 loop of gp120. Similarly, Trigonostema xyphophylloides from Euphorbiaceae and Vatica astrotricha from Dipterocarpaceae have been shown to act as HIV-1 entry inhibitors. These compounds likely inhibit HIV-1 replication by blocking the interaction between gp120 and CD4/CCR5 or gp120 and CD4/CXCR4. Petroleum ether from Rhus chinensis does not inhibit HIV-1 recombinant RT or HIV-1 entry into host cells, but may target new sites of HIV-1 replication [15]. Shikonin from the dried root of Lithospermum erythrorhizon is a pan-chemokine receptor inhibitor [16]. Lipophosphoglycan (LPG) from Leishmania donovani has been shown to inhibit the early stage of the HIV-1 life cycle by influencing the membrane fluidity of target cells and diminishing both the viruscell and cell-to-cell fusion processes initiated by HIV-1 [17].

Taraxacum officinale, also known as the common dandelion, has been shown to have heat clearing and detoxifying effects in addition to the ability to eliminate stagnation, remove stasis and induce diuresis for treating strangurtia. This plant is one of the common antiviral agents used in traditional Chinese medicines. Historically, it has been used to treat numerous diseases, ranging from infectious diseases; tumors of the breast, uterus and lung; kidney disease; digestive diseases; and diabetes. Some of the traditional applications of dandelion extract are supported by pharmacological investigation. Modern pharmacological research suggests this plant has broad-spectrum antibacterial [18], anti-fungal [19], antiviral, antidiabetic, choleretic, antirheumatic, anti-inflammatory [20,21], hepatoprotective [22], diuretic [23], and tumor apoptosis-inducing properties [24-26]. However, the antiretroviral properties of this plant have not been examined until recently.

Virus cell-based fluorescence assay using pseudotype particles is an efficient and cost-effective screening system and has been used for primary screening of novel agents against HIV-1 [27-30]. Pseudotyped viruses produced in this system can mimic most stages of the HIV1 life cycle, including viral protein production, assembly, release, maturation, entry, integration and replication without producing replication-competent viruses. This approach has the potential to identify inhibitors against multiple viral and cellular functions essential for HIV replication [30]. The level of HIV-1 replication has been assessed by the expression of reporter genes represented by the percentage of GFP-positive cells.

This study aimed to investigate the in vitro inhibitory effects of aqueous dandelion extract (DWE) on HIV-1 replication by utilizing VSV-G pseudotyped viruses to infect non-CD4 cells. Reverse transcriptase assay kit was used to detect inhibitory effect on RT enzyme activity of dandelion. These results suggest that dandelion extract has a potent inhibitory activity against HIV-1 replication and RT activity. The further investigation should include the identification of the active components in the dandelion extract.

\section{Methods}

\section{Cell lines and cell culture}

All cell lines, the mouse fibroblast cell line (NIH/3T3), 293T human renal epithelial cell, RetroPackPT67 packaging cells and Phoenix Eco packaging cells were purchased from ATCC (Rockville, MD, USA) and grown in Dulbecco's modified eagle medium (DMEM; GIBCO, USA) supplemented with $10 \%$ fetal bovine serum (FBS; Gibco, USA), $100 \mathrm{IU} / \mathrm{ml}$ penicillin and $100 \mu \mathrm{g} / \mathrm{ml}$ streptomycin. The cells were incubated in a humidified environment with $5 \% \mathrm{CO}_{2}$ at $37^{\circ} \mathrm{C}$. Peripheral mononuclear blood cells (PBMCs) were purified using Ficoll density gradient centrifugation from healthy donors supplied by the Beijing Blood Bank. PBMCs were resuspended and cultured in RPMI-1640 medium supplemented with $10 \%$ FBS and $100 \mathrm{U} / \mathrm{ml}$ recombinant human IL-2 overnight before they were used in the cytotoxicity assay. Based on an informed consent, this project was approved by the Biomedical Research Ethics Committee of CAS Key Laboratory of Pathogenic Microbiology and Immunology (NO.CASPMI009).

\section{Retroviral vector and packaging cell construction}

pLNCX2 contains elements derived from the Moloney murine leukemia virus (MoMuLV) and the Moloney murine sarcoma virus (MoMuSV) and is designed for retroviral gene delivery. The pLNCX2 retroviral vector (donated by professor Huang) was chosen to insert enhanced green fluorescent protein (EGFP). The EGFP gene was amplified by PCR using the following primers: EGFP-F, CCGCTCGAGGCCGCCAC CATGGTGAGCAAGGGCGAGGAGCT; EGFP-R, ACGCGTCGACCTACTTGTA CAGCTCGTCCATGCCGAGAGAGT, and the fragment was inserted into the pLNCX2 retroviral vector at the $\mathrm{XhoI} / \mathrm{Sal}$ I restriction enzyme site.

The Phoenix Eco packaging cells were transfected with pLNCX2-EGFP using calcium phosphate-based transfection. The retroviral supernatant was collected $48 \mathrm{~h}$ posttransfection, filtered through a $0.45 \mu \mathrm{m}$ filter and stored at $-80^{\circ} \mathrm{C}$ for subsequent use. RetroPack PT67 cells were 
subsequently infected with the retrovirus-containing supernatant in the presence of $8 \mu \mathrm{g} / \mathrm{ml}$ polybrene (Sigma Co., St Louis, MO) using centifugation at 1200 $\mathrm{xg}$ at $32^{\circ} \mathrm{C}$ for $90 \mathrm{~min}$. Six hours after infection, the supernatant was removed and the cells were incubated in the complete medium. The expression of the pLNCX2-EGFP retroviral vector was verified by selection with $100 \mu \mathrm{g} / \mathrm{ml} \mathrm{G418} \mathrm{(GIBCO,} \mathrm{USA).}$

The pLNCX2-EGFP-transfected RetroPack PT67 packaging cells encoding the EGFP genes were used as a stable EGFP virus-producing cell line and cultured in DMEM supplemented with $10 \%$ FBS. Retaining one plate for the continuation of the culture, the remaining cells were plated at $60-80 \%$ confluence in the desired number of culture vessels. Viral supernatants could then be harvested in $24 \mathrm{~h}$ intervals until the cells were no longer viable. Once the virus was harvested, all cells were discarded.

\section{Production of pseudotyped virus and transduction}

To produce single-cycle infectious virons, VSV-G pseudotyped HIV-1 vector stocks were prepared, concentrated and titered as described previously [31]. The pLL3.7 plasmid (6 $\mu$ g; Invitrogen, USA), belonging to the third generation of lentivirus vector system based on HIV-1, was co-transfected with pLP1 (Invitrogen, USA), pLP2 (Invitrogen, USA) and pLP/VSVG (Invitrogen, USA) into $293 \mathrm{~T}$ cells using calcium phosphate-based transfection. After transfection (48 to $72 \mathrm{~h}$ ), the viruscontaining supernatants were harvested, passed through a $0.45 \mu \mathrm{m}$ filter and frozen in aliquots at $-80^{\circ} \mathrm{C}$ until use. NIH/3T3 cells were placed in each well of a sixwell plate with $2 \mathrm{ml}$ DMEM containing 10\% FBS. The next day, the media was replaced with $2 \mathrm{ml}$ of virus supernatants containing $8 \mu \mathrm{g} / \mathrm{ml}$ of polybrene at a multiplicity of infection (MOI) of 1 in the presence or absence of DWE. Zidovudine (AZT) and Herba Artemisiae Scopariae were used as positive control and negative control respectively. The cells were infected by spinoculation in a centrifuge at $1,200 \mathrm{xg}$ for $90 \mathrm{~min}$ at $32^{\circ} \mathrm{C}$ and incubated at $37^{\circ} \mathrm{C}$ overnight, followed by a change to fresh medium.

\section{Plant material}

Samples of the entire plant of Taraxacum officinale (dried) and Herba Artemisiae Scopariae (dried) were purchased at Fenlinlvzhou medicinal store in Beijing, China in December 2010 and authenticated by ph.D Wei Li, Institute of Microbiology, Chinese Academy of Sciences. The voucher specimen of these plant materials were deposited in the CAS Key Laboratory of Pathogenic Microbiology and Immunology (CASPMI), Institute of Microbiology, Chinese Academy of Sciences.
Quantification of the inhibitory effect of DWE to HIV-1 RT The effect of DWE on HIV-1 RT activity was evaluated with the reverse transcriptase assay, coloremetric kit (Version 13.0, Roche, USA). The assay was performed according to the manufacture's instructions by transferring $20 \mu \mathrm{l}$ of recombinant HIV-1 RT and $20 \mu \mathrm{l}$ reaction buffer to microfuge tubes containing different concentrations of DWE $(2 \mathrm{mg} / \mathrm{ml}, 1 \mathrm{mg} / \mathrm{ml}, 0.75 \mathrm{mg} / \mathrm{ml}, 0.5$ $\mathrm{mg} / \mathrm{ml}, 0.25 \mathrm{mg} / \mathrm{ml}, 0.125 \mathrm{mg} / \mathrm{ml}$ ) and diluted with lysis buffer. $2.5 \mu \mathrm{M}$ AZT was used as a positive control, lysis buffer without HIV-1 RT was used as one negative control (control 1), lysis buffer with HIV-1 RT but no DWE was used as another negative control (control 2). After 1 $\mathrm{h}$ incubation at $37^{\circ} \mathrm{C}$, the samples were transfered into microplate modules for $1 \mathrm{~h}$ incubation again at $37^{\circ} \mathrm{C}$. The plate was rinsed 5 times with $250 \mu \mathrm{l}$ of washing buffer and buffer was completely removed before adding $200 \mu \mathrm{l}$ of anti-DIG-POD working dilution. A further $1 \mathrm{~h}$ incubation at $37^{\circ} \mathrm{C}$ followed by washing 5 times with washing buffer. $200 \mu \mathrm{l}$ ABTS substrate solution was added per well and incubated at room temperature until color development is sufficient for photometric detection (10-30 min). The absorbance was read on a microplate reader at $405 \mathrm{~nm}$ and a reference wavelength of $490 \mathrm{~nm}$. The assay was carried out in triplicate and repeated three times. Results were analyzed using the formula:

$$
\begin{aligned}
\% \text { relative inhibition } & =\left(\mathrm{RT}_{\text {control } 2}-\mathrm{RT}_{\text {control 1 }}\right)-\left(\mathrm{RT}_{\text {sample }}-\mathrm{RT}_{\text {control } 1}\right) \\
& \times 100 / \mathrm{RT}_{\text {control } 2}-\mathrm{RT}_{\text {control } 1}
\end{aligned}
$$

\section{Preparation of extracts}

$10 \mathrm{~g}$ of the dried whole plant of Taraxacum officinale and Herba Artemisiae Scopariae were respectively soaked in water for $0.5 \mathrm{~h}$ at room temperature. Hot water extractions were performed at $100^{\circ} \mathrm{C}$ in three batches: $200 \mathrm{ml}$ for $3 \mathrm{~h}, 150 \mathrm{ml}$ for $2 \mathrm{~h}, 100 \mathrm{ml}$ for $1 \mathrm{~h}$. The mixtures were then pooled together and filtered to remove the particulate matter, concentrated to $100 \mathrm{ml}$, filtered through a $0.22 \mu \mathrm{m}$ syringe filter and lyophilized, yielding light yellow power.

\section{Cell survival assay}

The cytotoxicity of DWE to NIH/3T3 cells was assessed using a CCK-8 assay (Cell Counting Kit, Dojindo Laboratories, Kumamoto, Japan). NIH3T3 cells were seeded in 96-well plates at an initial density of $3 \times 10^{3}$ cells/well in $100 \mu \mathrm{l}$ of culture medium. After $24 \mathrm{~h}$ of incubation, the cells were treated in the presence or absence of the different compounds at different concentrations ranging from $8 \mathrm{mg} / \mathrm{ml}$ to $0.25 \mathrm{mg} / \mathrm{ml}$ and 100 $\mu \mathrm{M}$ to $0.0001 \mu \mathrm{M}$ of AZT. The medium was removed, and the cells were washed twice with fresh media. Next, 
$100 \mu \mathrm{l}$ of fresh serum-free DMEM containing 1/10(v/v) Cell Counting Kit- 8 reagent was added to each well and incubated for an additional $4 \mathrm{~h}$. After incubation, the viability of the NIH/3T3 cells was assayed with CCK-8 using a 96-well plate reader (DG5032, Huadong, Nanjing, China) at $450 \mathrm{~nm}$. Untreated cells were served as the negative control, and wells containing the Cell Counting Kit-8 reagent and no cells were used as the blank control. Cytotoxicity was assessed by the cell survival rate. The absorbance reading from each well was used to calculate the cell survival rate. Survival rate (\%) = optical density (OD) of the treated cells -OD of blank control/OD of negative control-OD of blank control $\times 100$.

The cytotoxicity of DWE in human PBMCs was determined using the trypan blue exclusion method. Briefly, PBMCs were cultured at $1.3 \times 10^{6}$ cells $/ \mathrm{ml}$ in a 24 -well plate supplemented with $100 \mathrm{IU} / \mathrm{ml} \mathrm{IL-2}$ and exposed to increasing concentrations of DWE for $24 \mathrm{~h}$. PBMCs without DWE treatment were used as a control. The cells were stained with $0.2 \%$ trypan blue dye, and the total cells and viable cells were counted under a light microscope.

\section{Flow cytometry, fluorescence microscopy analysis and image acquisition}

NIH3T3 cells were harvested using a trypsin/EDTA solution, washed with ice-cold PBS three times and resuspended in PBS to a final concentration of $10^{6}$ cells/ $\mathrm{ml}$. Virus infection was measured in the absence or presence of increasing concentrations of DWE. The percentage of EGFP-positive cells was used to calculate the infection efficiency by flow cytometry using Guava EasyCyte (Guava Technologies, USA). All FACS data were analyzed using FlowJo software (Tree Star, Ashland OR). Images were acquired on a ZEISS Axiovert $200 \mathrm{M}$ microscope (Zeiss, Vienna, Austria) with a $40 \mathrm{x} / 0.55 \mathrm{NA}$ objective. The microscope and image acquisition were controlled by AxioVision software. For GFP observation, we used blue light excitation. Image processing, such as the clipping of images, was first performed in PowerPoint and then converted to TIFFs.

\section{High performance liquid chromatography(HPLC)}

$200 \mathrm{mg}$ freeze-dried aqueous extract powder was dissolved in $2 \mathrm{ml}$ milli-Q water, and filtered through a 0.22 $\mu \mathrm{m}$ syringe filter before analysis. HPLC separation was conducted by a Shimadzu CTO-15C system equipped with a binary high pressure gradient pump, UV/Vis detector SPD-15C. Peak areas were calculated with a LC solution $15 \mathrm{C}$ software. Gradient elution was performed using two solvents consisting of A $(0.1 \%(v / v)$ TFA in $\left.\mathrm{H}_{2} \mathrm{O}\right)$ and $\mathrm{B}((0.1 \%(\mathrm{v} / \mathrm{v})$ TFA in acetonitrile). Step gradient is from $5 \%$ to $70 \%$ of B over $40 \mathrm{~min}$. Total chromatography duration was $40 \mathrm{~min}$. The flow-rate of mobile phase was $1 \mathrm{ml} / \mathrm{min}$. Injection volume was $25 \mu \mathrm{l}$. The detection wavelengths were set at 254 and $323 \mathrm{~nm}$, and column temperature was room temperature. The caffeic acid and chlorogenic acid purchased from Sigma (USA) were used as the reference standards for quantitative assay. The concentrations of components present in DWE were identified by comparing chromatographic peaks with the retention time of individual standards.

\section{Statistical analysis}

Data are presented as mean \pm SD. The data were statistically evaluated using a one-way ANOVA to compare differences between the groups. A p-value of $<0.05$ was considered to be significant. The IC50 values were calculated using GraphPad Prism programme.

\section{Results}

\section{Production of the VSV-G pseudotyped HIV-1 virus and 10A1 pseudotyped pLNCX2-EGFP vector}

We chose EGFP as a reporter gene because its expression can be easily monitored. As illustrated in Figure 1A, expression of EGFP served as an indicator of viral replication. pLNCX2-EGFP was generated by inserting the EGFP gene downstream from the CMV promoter. Virus-producing RetroPack PT67 cells were established through a ping-pong method, which uses the virus from the Eco packaging cell line to infect RetroPack PT67 cells. Finally, a stable pLNCX2-EGFP transfected RetroPack PT67 cell line was selected using G418. As shown in Figure 1B, high level of EGFP was observed in all RetroPack PT67 cells. Our experimental design was showned in Figure $1 \mathrm{C}$.

\section{In vitro effects of Taraxacum officinale extracts on cell viability}

The dried whole plant of $T$. officinale was extracted with hot water, yielding DWE $(17 \% \mathrm{w} / \mathrm{w})$. It was important to assess whether the compounds were toxic to exclude a non-specific antiretroviral effect. We determined the effects of the extracts on cell survival in the absence of HIV-1 infection to establish a non-toxic working concentration of the DWE. The cytotoxicity of DWE in NIH/3T3 cells was evaluated using a CCK-8 assay. The experiments were repeated three times for six different concentrations $(0.25$ $\mathrm{mg} / \mathrm{ml}, 0.5 \mathrm{mg} / \mathrm{ml}, 1 \mathrm{mg} / \mathrm{ml}, 2 \mathrm{mg} / \mathrm{ml}, 4 \mathrm{mg} / \mathrm{ml}, 8 \mathrm{mg} / \mathrm{ml}$ ). For concentrations up to $2 \mathrm{mg} / \mathrm{ml}$, no significant cytotoxic effects were found (Figure 2A). The concentration of $2 \mathrm{mg} /$ $\mathrm{ml}$ was chosen to carry out the subsequent studies based on cell viability and morphological observations.

Taraxacum officinale extract has no toxicity in human PBMCs The cytotoxicity of DWE on human PBMCs was tested by evaluating cellular viability and was confirmed using the trypan blue test following exposure to increasing 


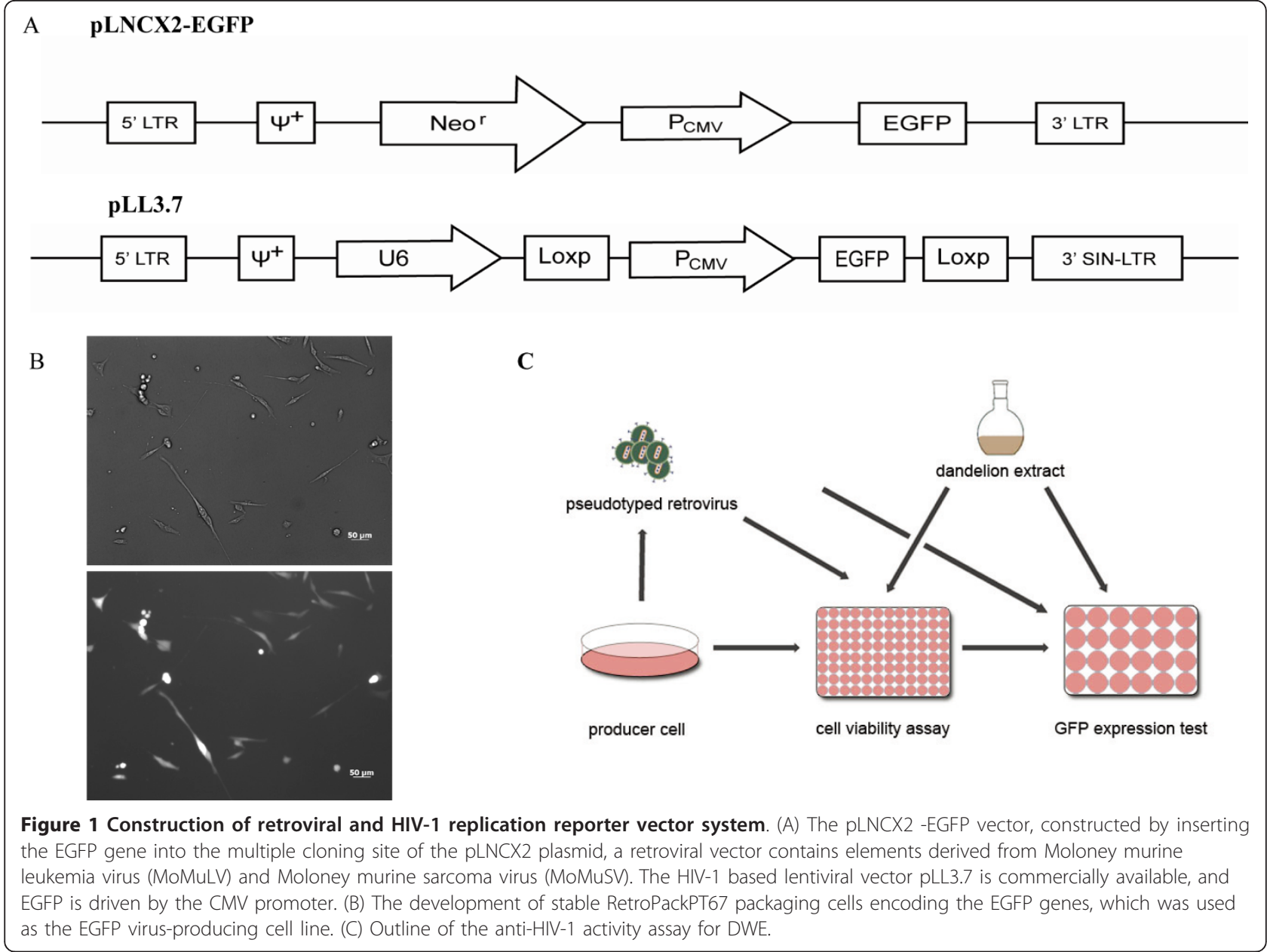

concentrations of DWE $(0.0625 \mathrm{mg} / \mathrm{ml}$ to $8 \mathrm{mg} / \mathrm{ml})$. As shown in Figure 2B, PBMC viability was not decreased at concentrations up to $8 \mathrm{mg} / \mathrm{ml}$. Compared to untreated PBMCs, both the number of total cells and the number of viable cells were significantly increased after treatment with DWE at a concentration of 0.0625 $\mathrm{mg} / \mathrm{ml}(\mathrm{p}<0.05)$. These data indicate that DWE exhibits no toxicity on human PBMCs and served as a nutrient or stimulator at a low concentration.

\section{Inhibitory activity of Taraxacum officinale extract on HIV-1 replication}

When compared to control values obtained from infected cells that were not treated with the plant extracts, DWE showed inhibitory activity that increased in a concentration-dependent manner. This was seen as a decrease of GFP-positive counts in a dose-dependent manner (see graphs in Figure 3). AZT, a reverse transcriptase inhibitor, was used as a positive control. As shown in Figure 4A, the $50 \%$ inhibitory concentration $\left(\mathrm{IC}_{50}\right)$ of AZT for HIV-1 was $0.29 \mu \mathrm{M}$, which is in accordance with previously published data. We used the previously determined non-toxic concentration of $2 \mathrm{mg} /$ $\mathrm{ml}$ as the starting testing point for DWE. The maximum inhibitory effect (98\%) was obtained with $2 \mathrm{mg} / \mathrm{ml}$, and the $\mathrm{IC}_{50}$ of DWE was $0.64 \mathrm{mg} / \mathrm{ml}$, As a negative control, the extract from Herba Artemisiae Scopariae showed much weaker inhibitory activity with an IC50 of 1.255 $\mathrm{mg} / \mathrm{ml}$ when compared to the activities of Taraxacum officinale observed. Next, we determined whether DWE was similarly effective in the inhibition of another retrovirus unrelated to HIV-1, the 10A1-pseudotyped hybridMoMuLV/MoMuSV retrovirus. We found DWE also to be effective for this virus. The maximum inhibitory effect (73\%) was obtained with $2 \mathrm{mg} / \mathrm{ml}$, and the $\mathrm{IC}_{50}$ of DWE was $0.23 \mathrm{mg} / \mathrm{ml}$ (Figure 4B). The similar ability of DWE to inhibit the replication of two unrelated retroviruses suggests that dandelion extract may target a factor that is broadly required for retroviral replication.

\section{Inhibitory effects of Taraxacum officinale extract on HIV-1} RT activity

Anti-HIV-1 activity of the aqueous extract of dandelion was further investigated using RT assay, which is a 


$$
\text { A }
$$

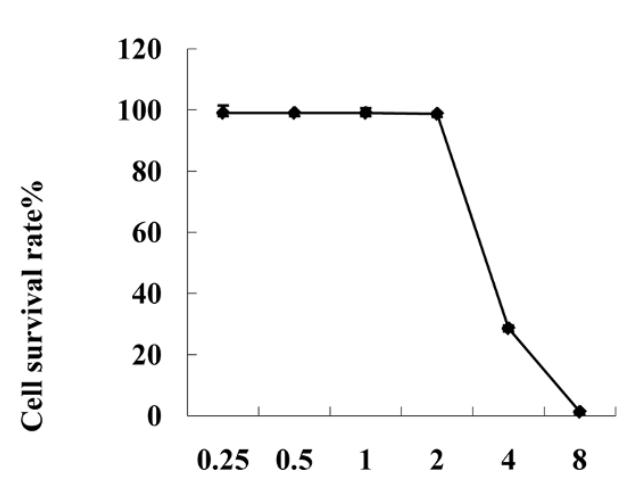

DWE(mg/ml)
B

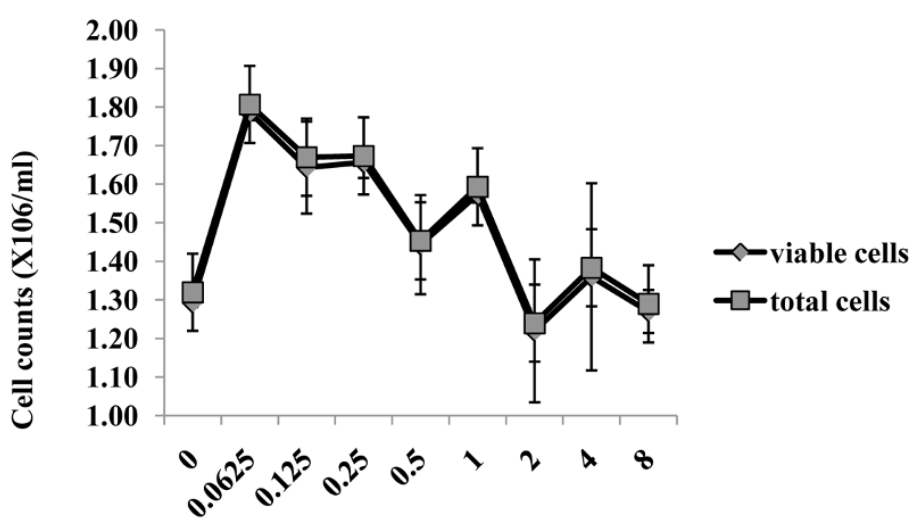

$\operatorname{DWE}(\mathbf{m g} / \mathrm{ml})$

PBMC

Figure 2 Cytotoxicity assay for different cells cultured with different concentrations of DWE. (A) NIH/3T3 cell survival curves from the CCK-8 assay. The negative control was untreated cells, and the blank control contained the Cell Counting Kit-8 reagent and no cells. The curve represents the average of three independent experiments with SD bars. (B) PBMCs were incubated at $37^{\circ} \mathrm{C}$ in $5 \% \mathrm{CO}_{2}$ overnight in media supplemented with IL-2 at a concentration of $100 \mathrm{IU} / \mathrm{ml}$. The cells were then exposed to the DWE for $24 \mathrm{~h}$, and aliquots of cells were stained with trypan blue dye to determine the total numbers of cells as well as viable cells. PBMC cells, cultured in the absence of DWE were used as control. These data represent three independent experiments.

colorimetric assay where the enzyme activity is determined after treatments in the presence or absence (untreated control) of different concentrations of DWE. Inhibition of DWE to the HIV-1 RT enzyme was evaluated based on their percent inhibition compared to a sample that does not contain DWE. As showned in Figure 4C, DWE showed potent inhibitory effect at 2 $\mathrm{mg} / \mathrm{ml}(94.89 \%)$ with an IC50 of $0.87 \mathrm{mg} / \mathrm{ml}$ compared

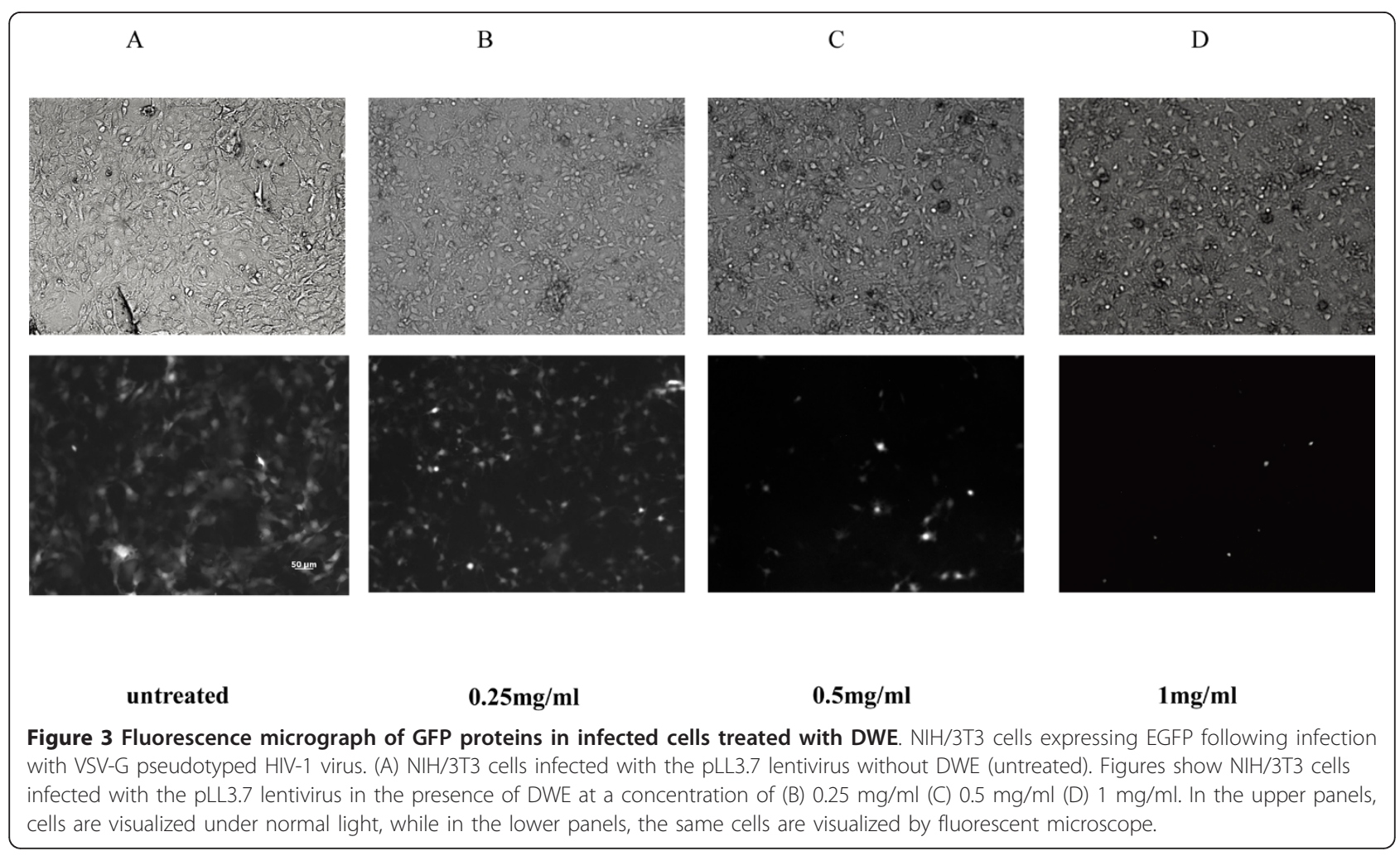




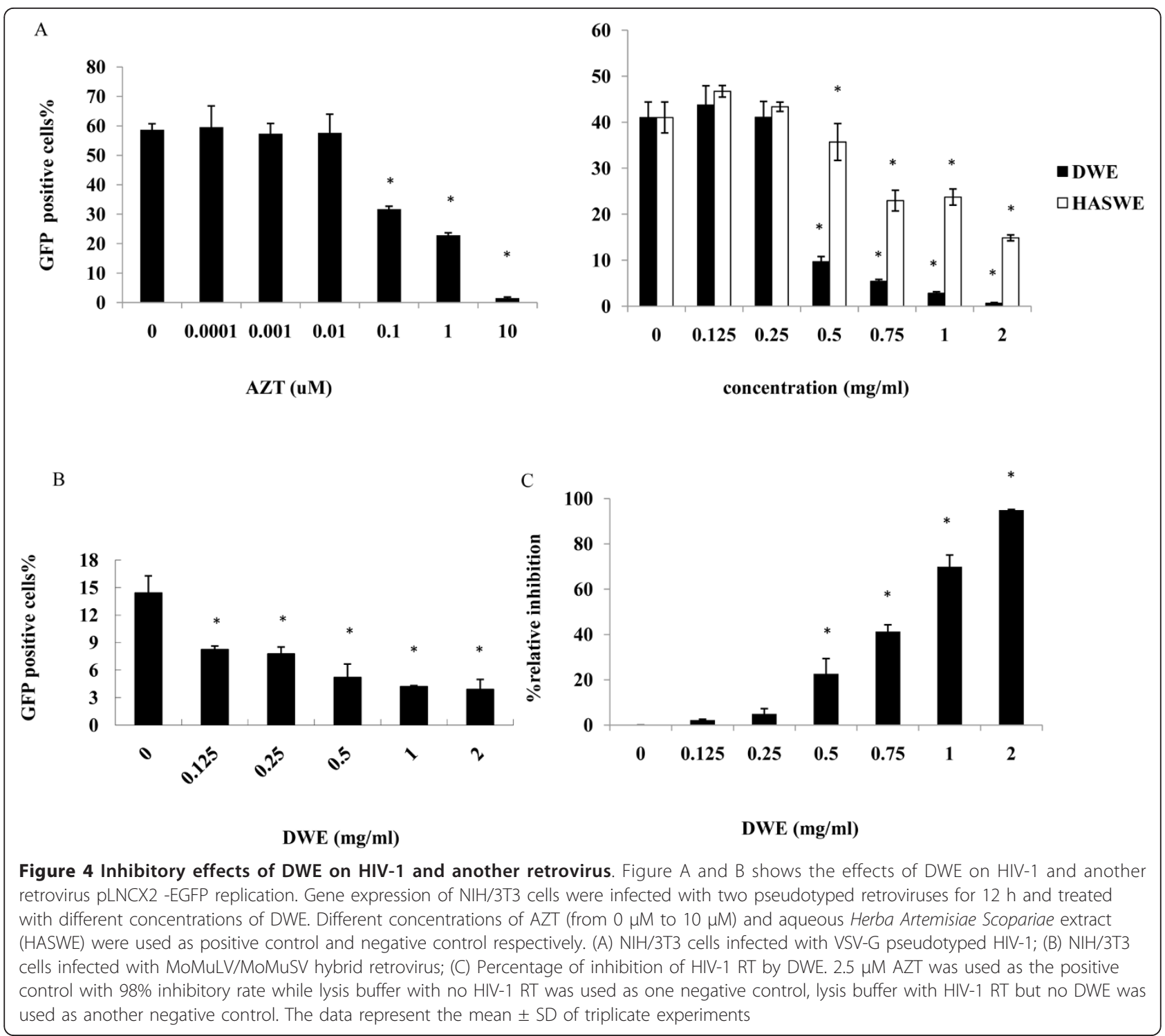

to RT inhibitor, AZT at $2.5 \mu \mathrm{M}(98 \%)$, and the inhibitory activities were dose dependent.

\section{Discussion}

The present study demonstrates for the first time that DWE displays inhibitory effect on HIV-1 replication and $\mathrm{RT}$ activitiy. It has been reported that extracts containing marked concentrations of chlorogenic acid inhibited HIV reverse transcriptase [32,33]. Dandelion are rich in phenolic compounds, in particular chlorogenic acid, caffeic acid, various flavonoid glycosides such as luteolin 7O-glucoside, luteolin and others, however, as shown in Figure 5, HPLC analysis of two Compositae plant species showed that Herba Artemisiae Scopariae extract, which contain higher contents of chlorogenic acid and caffeic acid than those in DWE (212-fold and 7-fold, respectively), showed milder inhibitory activity on HIV1 replication. Since DWE are mixture of components, there is a possibility that the anti-HIV-1 compound may be novel. The isolation of active components against HIV-1 RT from Taraxacum officinale is now in progress. The activity exhibited by DWE gives some evidence to validate their effect against HIV-1.

Cell-based assays are one of the high-throughput screening used to identify new inhibitors that target on different steps in the HIV-1 life cycle. Single-cycle infectious pseudotyping of HIV-1 using the envelope glycoprotein of the vesicular stomatitis virus (VSV-G) can mimic some behaviors of the wild-type viruses [34]. High-titer stocks of the single-cycle infectious virus can be generated from producer cells. In addition, using the single-cycle infectious viruses in HIV-1 reporter virus 


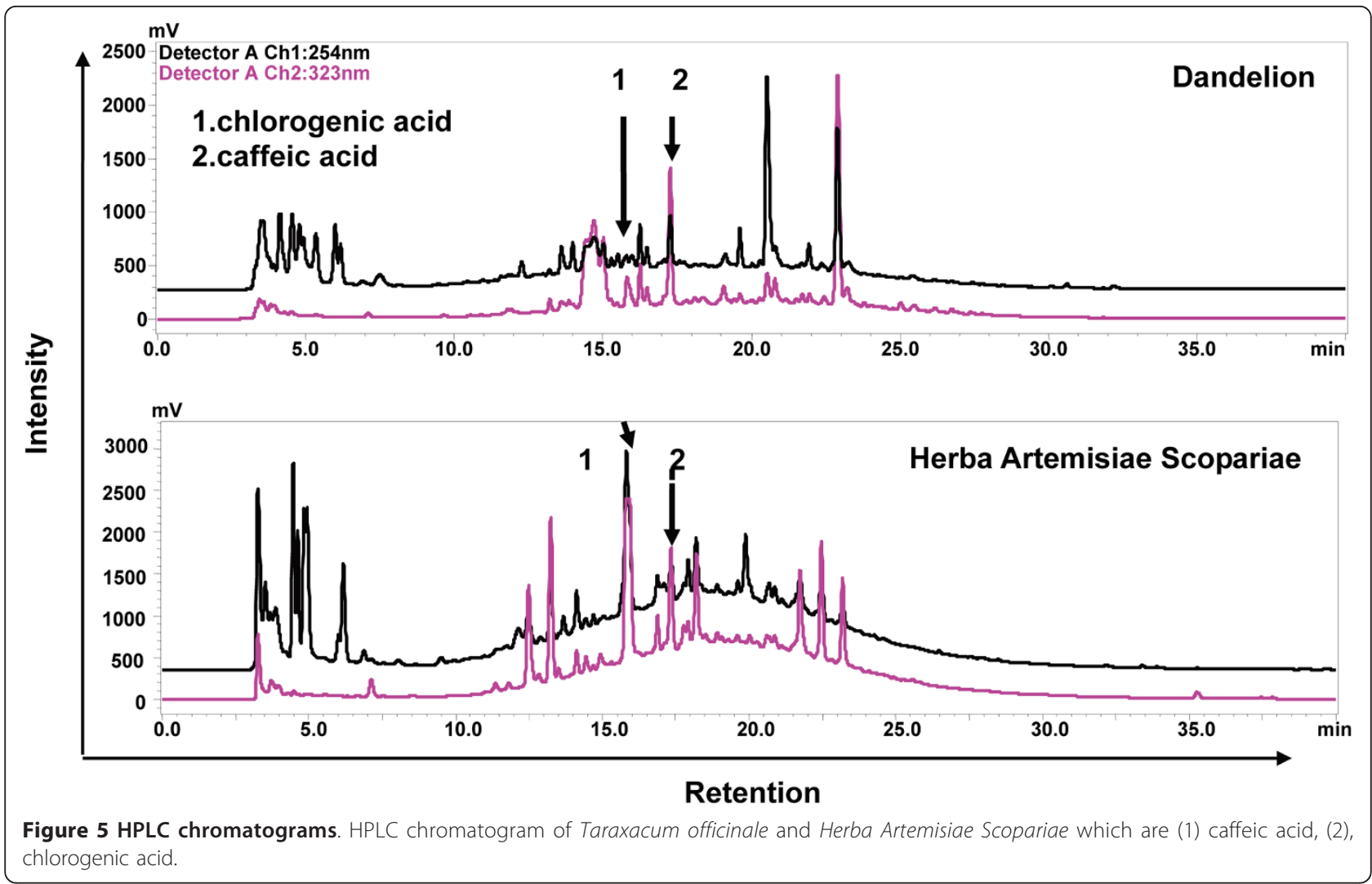

assays significantly reduces the safety risk encountered with replication-competent HIV-1. Taking these into account, experts emphasize the importance of developing cell-based screening systems for the rapid identification of novel anti-HIV agents [35-38]. Moreover, to explore the different mechanism of anti-HIV-1 activity, choosing an appropriate cell line is a critical step. Human CD4+ Jurkat cells are commonly used in screening anti-HIV-1 drugs $[6,39,40]$, but other reports have indicated dandelion root extract shows a selective induction of apoptosis through the activation of caspase- 8 in human leukemia cells (Jurkat) [26]. In our study, we used VSV-G pseudotyped HIV-1, which has a different entry pathway from wild-type HIV-1 [34], and a non-CD4 cell line. The assay used here targeted HIV-1 replication, a post-entry event. A deletion in the U3 region results in the loss of promoter activity following reverse transcription and integration. The only promoter that dictates the transcription of a reporter gene is the internal promoter CMV. Thus, the expression of GFP protein is a reliable indicator of HIV-1 replication [41]. It is also important to distinguish specific antiretroviral activity from non-specific inhibitor effects or DWE-mediated cytotoxicity. We combined cytotoxicity data with antiretroviral testing to solve this issue. DWE has been studied in mice, and it was reported that the administration of DWE at $1 \mathrm{~g} / \mathrm{kg} /$ day for 4 weeks did not produce adverse effects [22]. We also observed that DWE had no cytotoxic effect on primary PBMCs.

\section{Conclusions}

In conclusion, the dandelion extract showed strong activity against HIV-1 RT and inhibited both the HIV-1 vector and the hybrid-MoMuLV/MoMuSV retrovirus replication. These findings provide additional pharmacological information on the potential therapeutic efficacy of Taraxacum officinale. This could represent another starting point for the development of an anti-retroviral therapy with fewer side effects.

This preliminary finding suggested to isolate bioactive compound from biologically active extracts for further study. Components activity tests of the plants extracts would be performed for anti-HIV-1 activities. It is desirable to determine the effects of DWE on wild-type HIV1 as well as to try to isolate active constituents.

\section{Acknowledgements}

We thank Bhargavi M. Boruah, Ph.D for her careful reading the manuscript and helpful discussions. This work was supported by grants 2008ZX10003012 and 2009ZX10004-305.

\section{Author details}

'CAS Key Laboratory of Pathogenic Microbiology and Immunology (CASPMI), Institute of Microbiology, Chinese Academy of Sciences, Beijing, PR China. 
${ }^{2}$ Graduate University of Chinese Academy of Sciences, Beijing, PR China ${ }^{3}$ School of Life Sciences, University of Science and Technology of China, Hefei 230027, China. ${ }^{4}$ China-Japan Joint Laboratory of Molecular Immunology and Microbiology, Institute of Microbiology, Chinese Academy of Sciences, Beijing, PR China. ${ }^{5}$ Biochemistry Teaching and Research office of Hebei medical university, Shijiazhuang, PR China.

\section{Authors' contributions}

$\mathrm{HMH}$ performed experiments and prepared the manuscript. $\mathrm{WH}$ and $\mathrm{WW}$ performed experiments. BG designed the experiments, supervised the project. All authors read and approved the final manuscript.

\section{Competing interests}

The authors declare that they have no competing interests.

Received: 27 July 2011 Accepted: 14 November 2011 Published: 14 November 2011

\section{References}

1. Cohen J: AIDS research. Promising AIDS vaccine's failure leaves field reeling. Science 2007, 318:28-29.

2. Shafer RW, Schapiro JM: HIV-1 drug resistance mutations: an updated framework for the second decade of HAART. AIDS Rev 2008, 10:67-84.

3. Vo TS, Kim SK: Potential Anti-HIV Agents from Marine Resources: An Overview. Mar Drugs 2010, 8:2871-2892.

4. Jiang Y, Ng TB, Wang CR, Zhang D, Cheng ZH, Liu ZK, Qiao WT, Geng YQ, Li N, Liu F: Inhibitors from natural products to HIV-1 reverse transcriptase, protease and integrase. Mini Rev Med Chem 2010, 10:1331-1344.

5. Filho JR, de Sousa Falcao H, Batista LM, Filho JM, Piuvezam MR: Effects of plant extracts on HIV-1 protease. Curr HIV Res 2010, 8:531-544.

6. Park IW, Han C, Song X, Green LA, Wang T, Liu Y, Cen C, Yang B, Chen G, He JJ: Inhibition of HIV-1 entry by extracts derived from traditional Chinese medicinal herbal plants. BMC Complement Altern Med 2009, 9:29.

7. Singh IP, Bodiwala HS: Recent advances in anti-HIV natural products. Nat Prod Rep 2010, 27:1781-1800.

8. Asres K, Seyoum A, Veeresham C, Bucar F, Gibbons S: Naturally derived anti-HIV agents. Phytother Res 2005, 19:557-581.

9. Balestrieri E, Pizzimenti F, Ferlazzo A, Giofre SV, lannazzo D, Piperno A, Romeo R, Chiacchio MA, Mastino A, Macchi B: Antiviral activity of seed extract from Citrus bergamia towards human retroviruses. Bioorg Med Chem 2011.

10. Kashiwada Y, Hashimoto F, Cosentino LM, Chen CH, Garrett PE, Lee KH: Betulinic acid and dihydrobetulinic acid derivatives as potent anti-HIV agents. J Med Chem 1996, 39:1016-1017.

11. Qian K, Yu D, Chen CH, Huang L, Morris-Natschke SL, Nitz TJ, Salzwedel K, Reddick M, Allaway GP, Lee KH: Anti-AIDS agents. 78. Design, synthesis, metabolic stability assessment, and antiviral evaluation of novel betulinic acid derivatives as potent anti-human immunodeficiency virus (HIV) agents. J Med Chem 2009, 52:3248-3258.

12. Kanamoto T, Kashiwada Y, Kanbara K, Gotoh K, Yoshimori M, Goto T, Sano K, Nakashima H: Anti-human immunodeficiency virus activity of YKFH312 (a betulinic acid derivative), a novel compound blocking viral maturation. Antimicrob Agents Chemother 2001, 45:1225-1230.

13. Smith PF, Ogundele A, Forrest A, Wilton J, Salzwedel K, Doto J, Allaway GP, Martin DE: Phase I and II study of the safety, virologic effect, and pharmacokinetics/pharmacodynamics of single-dose 3-o-(3', 3'dimethylsuccinyl)betulinic acid (bevirimat) against human immunodeficiency virus infection. Antimicrob Agents Chemother 2007, 51:3574-3581.

14. Sun IC, Chen CH, Kashiwada Y, Wu JH, Wang HK, Lee KH: Anti-AIDS agents 49. Synthesis, anti-HIV, and anti-fusion activities of IC9564 analogues based on betulinic acid. J Med Chem 2002, 45:4271-4275.

15. Wang RR, Gu Q, Yang LM, Chen JJ, Li SY, Zheng YT: Anti-HIV-1 activities of extracts from the medicinal plant Rhus chinensis. J Ethnopharmacol 2006, 105:269-273.

16. Chen X, Yang L, Zhang N, Turpin JA, Buckheit RW, Osterling C, Oppenheim JJ, Howard OM: Shikonin, a component of chinese herbal medicine, inhibits chemokine receptor function and suppresses human immunodeficiency virus type 1. Antimicrob Agents Chemother 2003, 47:2810-2816.
17. Genois N, Barbeau B, Olivier M, Tremblay MJ: Inhibition of HIV-1-mediated syncytium formation and virus replication by the lipophosphoglycan from Leishmania donovani is due to an effect on early events in the virus life cycle. Clin Exp Immunol 2001, 124:32-42.

18. Woods-Panzaru S, Nelson D, McCollum G, Ballard LM, Millar BC, Maeda Y, Goldsmith CE, Rooney PJ, Loughrey A, Rao JR, Moore JE: An examination of antibacterial and antifungal properties of constituents described in traditional Ulster cures and remedies. Ulster Med J 2009, 78:13-15.

19. Odintsova TI, Rogozhin EA, Sklyar IV, Musolyamov AK, Kudryavtsev AM, Pukhalsky VA, Smirnov AN, Grishin EV, Egorov TA: Antifungal activity of storage $2 S$ albumins from seeds of the invasive weed dandelion Taraxacum officinale Wigg. Protein Pept Lett 2010, 17:522-529.

20. Koh YJ, Cha DS, Ko JS, Park HJ, Choi HD: Anti-inflammatory effect of Taraxacum officinale leaves on lipopolysaccharide-induced inflammatory responses in RAW 264.7 cells. J Med Food 13:870-878.

21. Park CM, Cha YS, Youn HJ, Cho CW, Song YS: Amelioration of oxidative stress by dandelion extract through CYP2E1 suppression against acute liver injury induced by carbon tetrachloride in Sprague-Dawley rats. Phytother Res 24:1347-1353.

22. You Y, Yoo S, Yoon HG, Park J, Lee YH, Kim S, Oh KT, Lee J, Cho HY, Jun W: In vitro and in vivo hepatoprotective effects of the aqueous extract from Taraxacum officinale (dandelion) root against alcohol-induced oxidative stress. Food Chem Toxicol 48:1632-1637.

23. Clare BA, Conroy RS, Spelman K: The diuretic effect in human subjects of an extract of Taraxacum officinale folium over a single day. J Altern Complement Med 2009, 15:929-934.

24. Schutz K, Carle R, Schieber A: Taraxacum-a review on its phytochemical and pharmacological profile. J Ethnopharmacol 2006, 107:313-323.

25. Chatterjee SJ, Ovadje P, Mousa M, Hamm C, Pandey S: The efficacy of dandelion root extract in inducing apoptosis in drug-resistant human melanoma cells. Evid Based Complement Alternat Med 2011, 2011:129045.

26. Ovadje P, Chatterjee S, Griffin C, Tran C, Hamm C, Pandey S: Selective induction of apoptosis through activation of caspase-8 in human leukemia cells (Jurkat) by dandelion root extract. J Ethnopharmacol 2011, 133:86-91.

27. Lindsten K, Uhlikova T, Konvalinka J, Masucci MG, Dantuma NP: Cell-based fluorescence assay for human immunodeficiency virus type 1 protease activity. Antimicrob Agents Chemother 2001, 45:2616-2622.

28. Blair WS, Isaacson J, Li X, Cao J, Peng Q, Kong GF, Patick AK: A novel HIV-1 antiviral high throughput screening approach for the discovery of HIV-1 inhibitors. Antiviral Res 2005, 65:107-116.

29. Cao J, Isaacson J, Patick AK, Blair WS: High-throughput human immunodeficiency virus type 1 (HIV-1) full replication assay that includes HIV-1 Vif as an antiviral target. Antimicrob Agents Chemother 2005, 49:3833-3841.

30. Kremb S, Helfer M, Heller W, Hoffmann D, Wolff H, Kleinschmidt A, Cepok S, Hemmer B, Durner J, Brack-Werner R: EASY-HIT: HIV full-replication technology for broad discovery of multiple classes of HIV inhibitors. Antimicrob Agents Chemother 2010, 54:5257-5268.

31. al Yacoub N, Romanowska M, Haritonova N, Foerster J: Optimized production and concentration of lentiviral vectors containing large inserts. J Gene Med 2007, 9:579-584

32. Chkhikvishvili ID, Kharebava Gl: Chicoric and chlorogenic acids in plant species from Georgia. Applied Biochemistry and Microbiology 2001, 37:188-191.

33. Kreis W, Kaplan MH, Freeman J, Sun DK, Sarin PS: Inhibition of Hiv Replication by Hyssop-Officinalis Extracts. Antiviral Research 1990, 14:323-337.

34. Aiken C: Pseudotyping human immunodeficiency virus type 1 (HIV-1) by the glycoprotein of vesicular stomatitis virus targets HIV-1 entry to an endocytic pathway and suppresses both the requirement for Nef and the sensitivity to cyclosporin A. J Virol 1997, 71:5871-5877.

35. Zhang H, Zhou Y, Alcock C, Kiefer T, Monie D, Siliciano J, Li Q, Pham P, Cofrancesco J, Persaud D, Siliciano RF: Novel single-cell-level phenotypic assay for residual drug susceptibility and reduced replication capacity of drug-resistant human immunodeficiency virus type 1. J Virol 2004, 78:1718-1729.

36. Petropoulos CJ, Parkin NT, Limoli KL, Lie YS, Wrin T, Huang W, Tian H, Smith D, Winslow GA, Capon DJ, Whitcomb JM: A novel phenotypic drug susceptibility assay for human immunodeficiency virus type 1 . Antimicrob Agents Chemother 2000, 44:920-928. 
37. Adelson ME, Pacchia AL, Kaul M, Rando RF, Ron Y, Peltz SW, Dougherty JP: Toward the development of a virus-cell-based assay for the discovery of novel compounds against human immunodeficiency virus type 1 . Antimicrob Agents Chemother 2003, 47:501-508.

38. Westby M, Nakayama GR, Butler SL, Blair WS: Cell-based and biochemical screening approaches for the discovery of novel HIV-1 inhibitors. Antiviral Res 2005, 67:121-140.

39. Daelemans D, De Clercq E, Vandamme AM: A quantitative GFP-based bioassay for the detection of HIV-1 Tat transactivation inhibitors. J Virol Methods 2001, 96:183-188.

40. Park IW, Han CR, Song XP, Green LA, Wang T, Liu Y, Cen CC, Song XM, Yang B, Chen GY, He JJ: Inhibition of HIV-1 entry by extracts derived from traditional Chinese medicinal herbal plants. Bmc Complementary and Alternative Medicine 2009, 9.

41. Dykes C, Demeter LM: Clinical significance of human immunodeficiency virus type 1 replication fitness. Clin Microbiol Rev 2007, 20:550-578.

Pre-publication history

The pre-publication history for this paper can be accessed here: http://www.biomedcentral.com/1472-6882/11/112/prepub

doi:10.1186/1472-6882-11-112

Cite this article as: Han et al.: Inhibitory effect of aqueous dandelion extract on HIV-1 replication and reverse transcriptase activity. BMC Complementary and Alternative Medicine 2011 11:112.

\section{Submit your next manuscript to BioMed Central and take full advantage of:}

- Convenient online submission

- Thorough peer review

- No space constraints or color figure charges

- Immediate publication on acceptance

- Inclusion in PubMed, CAS, Scopus and Google Scholar

- Research which is freely available for redistribution

Submit your manuscript at www.biomedcentral.com/submit 